\title{
Effects of Material Incentives and Non Material on Employee Satisfaction Employees Muhammad Azhar Mushlihin ${ }^{1}$ \\ Zulfikar Muhammad ${ }^{2}$ \\ Institut Agama Islam Negeri ( IAIN ) Manado \\ Sekolah Tinggi Ilmu Manajemen NITRO Makassar \\ Email : azharmus89@gmail.com
}

\begin{abstract}
The purpose of this study was to determine the effect of material and non-material incentives on employee job satisfaction at PT. Bank Tabungan Negara (Persero) Tbk. Makassar Branch.

The analysis method used to determine the effect of material and non-material incentives on employee job satisfaction is to use multiple linear regression analysis through the SPSS version 24.0 program.

Partially and simultaneously shows that the variables of material and non-material incentives can affect employee job satisfaction. These results imply that the company is able to create added value in the provision of additional wages which can ultimately increase the job satisfaction of its employees.

Keywords: Material Incentives, Non Material Incentives, Employee Satisfaction.

\section{Pengaruh Insentif Material dan Non Material Terhadap Kepuasan Kerja Karyawan Muhammad Azhar Mushlihin ${ }^{1}$ Zulfikar Muhammad ${ }^{2}$ \\ Institut Agama Islam Negeri ( IAIN ) Manado \\ Sekolah Tinggi Ilmu Manajemen NITRO Makassar \\ Email : azharmus89@gmail.com}

\begin{abstract}
Abstrak
Tujuan penelitian ini adalah untuk mengetahui pengaruh insentif material dan non material terhadap kepuasan kerja karyawan pada PT. Bank Tabungan Negara (Persero) Tbk. Cabang Makassar.

Adapun metode analisis yang digunakan untuk mengetahui pengaruh insentif material dan non material terhadap kepuasan kerja karyawan adalah dengan menggunakan analisis regresi linier berganda melalui program SPSS versi 24.0.

Secara parsial dan simultan menunjukkan bahwa variabel insentif material dan non material dapat mempengaruhi kepuasan kerja karyawan. Hasil ini mengimplikasikan bahwa perusahaan yang mampu menciptakan nilai tambah dalam pemberian tambahan upah yang pada akhirnya dapat meningkatkan kepuasan kerja karyawannya.
\end{abstract}

Kata Kunci: Insentif Material, Insentif Non Material, Kepuasan Kerja Karyawan.

\section{Pendahuluan}

Manajemen sumber daya manusia merupakan salah satu bidang manajemen yang khusus mempelajari hubungan dan peranan manusia dalam organisasi yang berperan mengatur tenaga kerja yang ada di dalam organisasi, sehingga terwujud tujuan organisasi. Manajemen sumber daya manusia juga dapat menghasilkan kinerja yang baik dalam sebuah perusahaan dengan cara penilaian, pemberian balas jasa dalam setiap individu anggota organisasi sesuai dengan kemampuan kerjanya.

Setiap anggota dari suatu organisasi mempunyai kepentingan dan tujuan sendiri ketika ia bergabung pada organisasi tersebut. Bagi sebagian karyawan, harapan untuk mendapatkan uang adalah satu-satunya alasan untuk bekerja, namun yang lain 
berpendapat bahwa uang hanyalah salah satu dari banyak kebutuhan yang terpenuhi melalui kerja.

Banyak perusahaan yang tidak dapat berjalan dengan baik di mana penyebabnya bukan dikarenakan modal yang dimiliki, tetapi dikarenakan oleh buruknya manajemen yang dimiliki termasuk manajemen sumber daya manusia. Sumber daya manusia dalam hal tenaga kerja sangat berperan penting dalam perusahaan, sehingga dibutuhkan tenaga kerja yang berkinerja baik untuk mendukung pengembangan perusahaan dan berhasil mencapai tujuan, khususnya di bidang perbankan.

PT. Bank Tabungan Negara (Persero) Tbk. Cabang Makassar adalah cabang utama wilayah Sulawesi Selatan yang merupakan salah satu Perusahaan Badan Usaha Milik Negara yang bergerak dalam bidang perbankan. Salah satu misi dari perusahaan ini adalah menyiapkan dan mengembangkan Human Capital yang berkualitas, profesional, dan memiliki integritas tinggi. Human Capital yang berkualitas, profesional akan hadir apabila perusahaan senantiasa memberikan kesejahteraan kepada setiap karyawannya. Hal ini diharapkan dapat meningkatkan kepuasan kerja dan mengantarkan karyawan dalam menghasilkan kinerja yang maksimal yang diharapkan perusahaan. Salah satu upaya untuk meningkatkan kepuasan seorang karyawan di perusahaan adalah dengan cara pemberian insentif yang sebanding dengan pekerjaan yang telah karyawan lakukan. Apabila seseorang yang telah bekerja melampaui target membuat karyawan mendapatkan insentif dari hasil kinerja yang telah dicapai.

Insentif adalah tambahan balas jasa yang diberikan kepada karyawan tertentu yang prestasinya di atas prestasi standar (Hasibuan, 2013:118). Pemberian insentif ini dimaksudkan agar karyawan tetap mau bekerja dengan baik dan lebih mencapai tingkat kinerja yang lebih tinggi. Insentif dapat dibagi menjadi dua golongan (Sarwoto, 2010:156). Pertama, insentif material yang berupa bonus, komisi, profit share, kompensasi program balas jasa yang mencakup pembayaran dikemudian hari. Kedua, insentif non-material yang berupa pemberian gelar (title) secara resmi, pemberian piagam penghargaan, pemberian pujian lisan maupun tulisan, ucapan terima kasih secara formal atau informal. Pemberian balas jasa berupa insentif material dan non material ini diharapkan karyawan merasa puas atas pekerjaannya.

Hal diatas sesuai dengan yang dikemukakan oleh Robbins (2006:120) bahwa apabila pemberian insentif itu adil dengan apa yang didasarkan pada tuntutan pekerjaan, tingkat keterampilan individu, dan pengupahan komunitas, kemungkinan besar akan di hasilkan kepuasan. Kepuasan kerja adalah sikap emosional yang menyenangkan dan mencintai pekerjaannya (Hasibuan, 2013:202). Karyawan akan bekerja dengan sungguh - sungguh apabila keinginan mereka telah terpuaskan. Kepuasan yang mereka rasakan akan berdampak pada pekerjaan yang mereka kerjakan.

Hal tersebut sesuai dengan penelitian yang dilakukan oleh Zaputri, dkk. (2013) dengan hasil penelitian menunjukkan bahwa insentif material dan non material berpengaruh signifikan terhadap kepuasan kerja karyawan pada PT. Temprina Media Grafika Surabaya.

Dengan ini maka peneliti akan menindaklanjuti dan melihat kondisi karyawan pada PT. Bank Tabungan Negara (Persero) Tbk. Cabang Makassar. Hal inilah yang menjadi dasar penulis melakukan penelitian dengan judul "Pengaruh Insentif Material dan Non Material Terhadap Kepuasan Kerja Karyawan Pada PT. Bank Tabungan Negara (Persero) Tbk. Cabang Makassar"

\section{Rumusan Masalah}


Berdasarkan latar belakang yang telah dijelaskan sebelumnya, maka yang menjadi rumusan masalah dalam penelitian ini sebagai berikut:

1. Apakah insentif material berpengaruh terhadap kepuasan kerja kayawan pada PT. Bank Tabungan Negara (Persero) Tbk. Cabang Makassar?

2. Apakah insentif non material berpengaruh terhadap kepuasan kerja karyawan pada PT. Bank Tabungan Negara (Persero) Tbk. Cabang Makassar?

3. Apakah insentif material dan non material berpengaruh terhadap kepuasan kerja karyawan pada PT. Bank Tabungan Negara (Persero) Tbk. Cabang Makassar?

\section{Tujuan Penelitian}

1. Tujuan Penelitian

Berdasarkan rumusan masalah diatas, adapun tujuan dalam penelitian ini yaitu :

a. Untuk mengetahui apakah insentif material berpengaruh terhadap kepuasan kerja karyawan pada PT. Bank Tabungan Negara (Persero) Tbk. Cabang Makassar.

b. Untuk mengetahui apakah insentif non material berpengaruh terhadap kepuasan kerja karyawan pada PT. Bank Tabungan Negara (Persero) Tbk. Cabang Makassar.

c. Untuk mengetahui apakah insentif material dan non material secara simultan berpengaruh terhadap kepuasan kerja karyawan pada PT. Bank Tabungan Negara (Persero) Tbk. Cabang Makassar.

\section{Tinjuan pustaka}

\section{A. Landasan teori}

\section{Insentif}

a. Pengertian Insentif

Insentif sebagai sarana motivasi yang mendorong para pegawai untuk bekerja dengan kemampuan yang optimal, yang dimaksudkan sebagai pendapatan ekstra di luar gaji atau upah yang telah ditentukan. Pemberian insentif dimaksudkan agar dapat memenuhi kebutuhan para pegawai dan keluarga mereka. Istilah sistem insentif pada umumnya digunakan untuk menggambarkan rencana pembayaran upah yang dikaitkan secara langsung atau tidak langsung dengan berbagai standar kinerja pegawai atau profitabilitas organisasi. Insentif dapat dirumuskan sebagai balas jasa yang memadai kepada pegawai yang prestasinya melebihi standar yang telah ditetapkan.

Kompensasi dan insentif mempunyai hubungan yang sangat erat, di mana insentif merupakan komponen dari kompensasi dan keduanya sangat menentukan dalam pencapaian tujuan dan sasaran organisasi secara keseluruhan. Insentif merupakan suatu faktor pendorong bagi pegawai untuk bekerja lebih baik agar kinerja pegawai dapat meningkat.

Dari pengertian di atas untuk lebih jelas tentang insentif, di bawah ini ada beberapa ahli manajemen mengemukakan pengertian mengenai insentif. Menurut Hasibuan (2013:118) mengemukakan pengertian insentif adalah tambahan balas jasa yang diberikan kepada karyawan tertentu yang prestasinya di atas prestasi standar. Insentif ini merupakan alat yang dipergunakan sebagai pendukung prinsip adil dalam pemberian kompensasi.

Panggabean (2002:93) mengemukakan bahwa Insentif adalah kompensasi yang mengaitkan gaji dengan produktivitas, insentif merupakan penghargaan dalam bentuk uang yang diberikan kepada mereka yang dapat bekerja melampaui standar yang telah ditentukan. 
Dari uraian konsep di atas dapat dimaknai bahwa insentif diberikan secara sengaja kepada karyawan agar terciptanya suatu dorongan untuk meningkatkan prestasi kerja sehingga akan menimbulkan dampak baik bagi perusahaan dengan adanya kinerja yang baik dan berkualitas. Berdasarkan pendapat di atas dapat disimpulkan bahwa insentif merupakan penghasilan di luar gaji pokok yang diberikan perusahaan terhadap karyawannya dengan memperhitungkan hasil kerja yang dicapai, sehingga karyawan terdorong untuk meningkatkan prestasi dalam rangka mencapai produktivitas dan hasil kerja sesuai dengan tujuan perusahaan. Pemberian insentif juga dapat diharapkan dapat meningkatkan kepuasan kerja karyawan dan tetap bekerja di perusahaan yang bersangkutan.

b. Jenis - Jenis Insentif

Insentif yang berarti penghargaan atau ganjaran ternyata tidak sekedar berbentuk upah atau gaji atas pengangkatannya sebagai tenaga kerja sebuah perusahaan. Menurut Nawawi (2011:317) penghargaan atau ganjaran sebagai insentif dibedakan dalam beberapa jenis sebagai berikut :

1) Kompensasi atau Insentif Total

Keseluruhan penghargaan atau ganjaran yang diterima oleh seseorang tenaga kerja untuk seluruh pekerjaannya yang dilakukannya sebagai kontribusi pada pencapaian tujuan organisasinya.

2) Kompensasi Khusus

Penghasilan tambahan yang diberikan kepada tenaga kerja dengan status tertentu dalam perusahaan.

Menurut Siagian (2007:268) jenis - jenis insentif sebagai berikut :

1) Piece Work (upah per output) adalah teknik yang digunakan untuk mendorong kinerja kerja pegawai berdasarkan hasil pekerjaan pegawai yang dinyatakan dalam jumlah unit produksi.

2) Production Bonus (bonus produksi) adalah insentif yang diberikan kepada pegawai yang mampu bekerja sedemikian rupa sehingga tingkat produksi yang baku terlampaui.

3) Commisions (komisi) adalah bonus yang diterima karena berhasil melaksanakan tugas dan sering diterapkan oleh tenaga-tenaga penjualan.

4) Executives Incentives (insentif eksekutif) adalah insentif yang diberikan kepada pegawai khususnya manajer atau pegawai yang memiliki kedudukan tinggi dalam suatu perusahaan, misalnya untuk membayar cicilan rumah, kendaraan bermotor atau biaya pendidikan anak.

5) Maturity Curve (kurva kematangan) adalah diberikan kepada tenaga kerja, yang karena masa kerja dan golongan pangkat serta gaji tidak bisa mencapai pangkat dan penghasilan yang lebih tinggi lagi, misalnya dalam bentuk penelitian ilmiah atau dalam bentuk beban mengajar yang lebih besar dan sebagainya.

6) Rencana insentif kelompok adalah kenyataan bahwa dalam banyak organisasi, kinerja bukan karena keberhasilan individual melainkan karena keberhasilan kelompok kerja yang mampu bekerja sebagai suatu tim.

Sementara menurut Sarwoto (2010:156) secara garis besar keseluruhan insentif dapat dibagi menjadi 2 golongan:

1) Insentif Material Insentif dalam bentuk uang

1) Bonus 
Uang yang diberikan sebagai balas jasa atas hasil kerja yang telah dilaksanakan, biasanya diberikan secara selektif dan khusus kepada para pekerja yang berhak menerima dan diberikan secara sekali terima tanpa suatu ikatan di masa yang akan datang. Perusahaan yang menggunakan sistem insentif ini biasanya beberapa persen dari laba yang melebihi jumlah tertentu dimasukkan kedalam sebuah dana bonus, kemudian dana tersebut dibagi - bagi antara pihak yang menerima bonus.

2) Komisi

Merupakan jenis bonus yang dibayarkan kepada pihak yang menghasilkan penjualan yang baik, biasanya dibayarkan dan diterimakan kepada para pekerja.

3) Pembagian laba (Profit Share)

Salah satu jenis insentif tertua. Pembayarannya dapat diikuti bermacam - macam pola, tetapi biasanya mencakup pembayaran berupa sebagian dari laba bersih yang disetorkan kedalam sebuah dana dan kemudian dimasukkan kedalam pendapatan setiap peserta.

4) Kompensasi

Program balas jasa yang mencakup pembayaran di kemudian hari, antara lain berupa :

(1) Pensiun, mempunyai nilai insentif karena memenuhi

(2) salah satu kebutuhan pokok manusia, yaitu menyediakan jaminan ekonomi bagi karyawan setelah tidak bekerja lagi.

(3) Pembayaran kontraktual, adalah pelaksanaan perjanjian antara atasan dan karyawan, dimana setelah selesai masa kerja karyawan dibayarkan sejumlah uang tertentu selama periode tertentu.

2) Insentif Non Material

Insentif non material ini dapat diberikan dalam berbagai bentuk, antara lain :

1) Pemberian gelar (title) secara resmi.

2) Pemberian piagam penghargaan.

3) Pemberian pujian lisan maupun tulisan secara resmi ataupun secara pribadi.

4) Ucapan terima kasih secara formal atau informal.

Dengan adanya jenis - jenis insentif ini maka perusahaan mampu mendorong motivasi dan gairah kerja pegawai, sehingga pegawai akan terus menjaga dan meningkatkan hasil kerjanya dan pada akhirnya pula akan meningkatkan keuntungan tersendiri dalam pencapaian tujuan yang telah ditetapkan.

c. Tujuan Insentif

Tujuan diberikannya insentif menurut Sutrisno (2011:188) sebagai berikut :

1) Menghargai prestasi kerja.

2) Menjamin keadilan.

3) Mempertahankan karyawan.

4) Memperoleh karyawan yang bermutu.

5) Pengendalian biaya.

6) Memenuhi peraturan.

d. Faktor Yang Mempengaruhi Insentif

Faktor-faktor yang harus diperhitungkan dalam menetapkan tingkat insentif, agar dirasakan sebagai faktor yang meningkatkan motivasi kerja. Faktor - faktor 


\section{Metode penelitian}

tersebut akan menentukan juga tingkat insentif yang kompetitif. Menurut Sirait (2006:202) yang mempengaruhi tingkat insentif adalah sebagai berikut :

1) Kondisi dan kemampuan dari perusahaan.

2) Kemampuan, kreativitas, serta prestasi dari karyawan.

3) Keadaan ekonomi suatu negara.

\section{A. Jenis dan sumber data}

1. Jenis Data

Adapun jenis data yang digunakan adalah sebagai berikut :

a. Data Kuantitatif

Adalah data yang diperoleh dalam bentuk angka-angka yang dapat dihitung.

Seperti jumlah karyawan yang bekerja pada PT. Bank Tabungan Negara (Persero) Tbk. Cabang Makassar.

b. Data Kualitatif

Adalah data yang diperoleh dari hasil kuesioner yang dibagikan kepada karyawan yang bekerja pada PT. Bank Tabungan Negara (Persero) Tbk. Cabang Makassar.

2. Sumber Data

Untuk menunjang kelengkapan pembahasan dalam penulisan proposal ini, penulis memperoleh data yang bersumber dari data primer. Data primer yaitu sumber data yang langsung memberikan data kepada pengumpul data (Sugiyono, 2017). Dalam penelitian ini, data primer didapat langsung dari responden dengan cara menyebarkan kuesioner kepada karyawan yang bekerja pada PT. Bank Tabungan Negara (Persero) Tbk. Cabang Makassar.

\section{Teknik Pengumpulan Data}

Teknik yang digunakan dalam memperoleh data yang dibutuhkan dalam penelitian ini adalah:

1. Penelitian Pustaka (Library Research)

Yaitu penelitian yang mempelajari referensi, buku-buku dengan karya ilmiah yang ada kaitannya dengan masalah dalam penelitian ini.

2. Penelitian Lapangan (Field Research)

Adalah penelitian yang dilakukan secara pengumpulan data kuisioner, merupakan suatu lembar isian yang di dalamnya berisi pertanyaan - pertanyaan yang harus dijawab oleh karyawan atau responden.

\section{B. POPULASI DAN SAMPEL}

1. Populasi

Adalah wilayah generalisasi yang terdiri dari atas obyek atau subyek yang mempunyai kualitas dan karakteristik tertentu yang ditetapkan oleh peneliti untuk dipelajari dan kemudian ditarik kesimpulannya (Sugiyono, 2017:119). Populasi dalam penelitian ini adalah seluruh karyawan yang bekerja pada PT. Bank Tabungan

Negara (Persero) Tbk. Cabang Makassar sebanyak 211 orang.

2. Sampel

Sampel adalah sebagian dari jumlah dan karakteristik yang dimiliki oleh populasi (Sugiyono, 2017:120). Teknik pengambilan sampel biasanya didasarkan oleh pertimbangan tertentu, misalnya keterbatasan waktu, tenaga dan dana sehingga tidak dapat mengambil sampel yang besar dan jauh. 
Adapun cara dalam penentuan sampel, penulis menggunakan cara purposive sampling. Hal ini dilakukan dengan cara mengambil subjek bukan didasarkan atas strata atau daerah tetapi didasarkan atas adanya tujuan tertentu.

Sugiyono (2017:126) menjelaskan bahwa purposive sampling adalah teknik penentuan sampel dengan pertimbangan tertentu, misalnya orang tersebut dianggap mengetahui tentang hal - hal yang berkaitan dengan penelitian ini. Dalam hal ini penulis mengambil sampel berdasarkan beberapa kriteria, diantaranya adalah:

a. Karyawan yang bekerja pada consumer collection \& remedial unit.

b. Kayawan yang telah mendapatkan insentif material dan non material.

\section{Tabel 3.1}

Kriteria Sampel

\begin{tabular}{|c|l|c|}
\hline No & \multicolumn{1}{|c|}{ Kriteria Sampel } & Sampel \\
\hline 1 & $\begin{array}{l}\text { Karyawan yang bekerja pada consumer collection } \\
\text { \& remedial unit. }\end{array}$ & 32 \\
\hline
\end{tabular}

Lanjutan tabel 3.1

\begin{tabular}{|c|l|c|}
\hline 2 & $\begin{array}{l}\text { Karyawan yang telah mendapatkan insentif material } \\
\text { dan non material. }\end{array}$ & 30 \\
\hline \multicolumn{2}{|c|}{ Jumlah Sampel } & $\mathbf{3 0}$ \\
\hline
\end{tabular}

Sumber: Data diolah, 2018

Berdasarkan pada kriteria pengambilan sampel seperti yang telah disebutkan di atas, maka jumlah sampel yang digunakan dalam penelitian ini adalah 30 karyawan.

\section{Definisi Operasional Variabel}

Dalam penenlitian ini digunakan beberapa istilah sehingga didefinisikan secara operasional agar menjadi petunjuk dalam penelitian ini. Adapun variabel yang digunakan dalam penelitian ini adalah :

\section{Variabel Independen $(X)$}

a. Insentif Material $\left(\mathrm{X}_{1}\right)$

Adalah tambahan penghasilan yang dapat dinilai dengan uang yang diberikan untuk memperbesar gairah kerja, antara lain:

1) Bonus, 2). Komisi, 3). Pembagian laba (Profit shar), 4). Kompensasi

b. Insentif Non Material $\left(\mathrm{X}_{2}\right)$

Adalah tambahan penghasilan yang diberikan tidak dalam bentuk uang. Insentif non material ini dapat diberikan dalam

berbagai bentuk, antara lain :

1). Pemberian gelar (title) secara resmi, 2). Pemberian piagam penghargaan,

3). Pemberian pujian lisan maupun tulisan secara resmi ataupun secara pribadi, 4). Ucapan terima kasih secara formal atau informal

\section{Variabel Dependen (Y)}

Kepuasan kerja merupakan perilaku dan perasaan senang maupun tidak senang karyawan terhadap pekerjaannya. Dengan kata lain, kepuasan kerja mencerminkan apa yang seorang pekerja rasakan mengenai pekerjaannya, dengan indikatornya adalah:

1) Rasa senang terhadap pekerjaannya, 2). Rasa cinta terhadap pekerjaannya, 3). Moral kerja, 4). Prestasi kerja

\section{Analisis Data}

\section{Teknik pengukuran}


Metode analisis yang digunakan adalah deskriptif kuantitatif dengan alat bantu melalui kuisioner yang dihitung dengan skala Likert (Sugiyono, 2017:136). Skala Likert adalah untuk memungkinkan karyawan dapat menjawab pernyatan dari setiap butir variabel kuisioner.

Dalam kuisioner ini terdapat variasi nilai dari jawaban yang telah diberikan oleh responden. Nilai tersebut berupa angka 1 sampai dengan 5, dimana tiap angka memiliki kualitas yang berbeda. Jawab di hubungkan dengan bentuk pertanyaan atau didukung sikap yang diungkapkan dengan kata-kata.

\section{Analisis Regresi Linear Berganda}

Analisis Linear Berganda berguna untuk menganalisis

hubungan linear antara 2 variabel independen atau lebih dengan

1 variabel dependen. Pengujian kebenaran hipotesis dalam peneliti ini yaitu

$$
Y=a+b_{1} X_{1}+b_{2} X_{2}+e
$$

modelnya sebagai berikut :

Dimana:

$$
\begin{array}{cc}
\mathrm{Y} & =\text { Kepuasan Kerja Karyawan } \\
\mathrm{a} & =\text { Konstanta } \\
\mathrm{X} 1 & =\text { Insentif Material } \\
\mathrm{X} 2 & =\text { Insentif Non Material } \\
\mathrm{b} 1 & =\text { Koefisien regresi X1 } \\
\mathrm{b} 2 & =\text { Koefisien regresi X2 } \\
\mathrm{e} & =\text { Standar } \text { error }
\end{array}
$$

\section{Uji Instrumen}

\section{a. Uji Validitas}

Menurut Sugiyono (2017:139) uji validitas merupakan kemampuan dari indikator-indikator untuk mengukur tingkat keakuratan sebuah konsep. Artinya apakah konsep tersebut sudah valid atau belum. Dikatakan valid jika nilai korelasi diatas 0,03 .

b. Uji Reliabilitas

Menurut Sugiyono (2017:140) uji reliabilitas adalah indeks yang menunjukkan sejauh mana suatu alat pengukur dapat dipercaya atau diandalkan. Reliabilitas menunjukkan konsistensi suatu alat pengukur didalam mengukur gejala yang sama. Dimana dikatakan reliable jika cronbach alpha > 0,6.

\section{Uji Asumsi Klasik}

\section{a. Uji Normalitas}

Uji normalitas bertujuan untuk untuk menentukan data atau nilai yang telah dikumpulkan berdistribusi normal atau diambil dari populasi normal. Salah satu cara untuk melihat normalitas adalah secara visual melalui Normal Probability Plot (P-Plot) (Basuki dan Prawoto, 2016:57).

Pada prinsipnya, normalitas (normal p-plot) dapat dideteksi dengan melihat penyebaran data (titik) pada sumbu diagonal grafik dengan melihat histogram dari residualnya. Adapun dasar pengambilan keputusan, yakni:

1) Jika data penyebaran disekitar garis diagonal dan mengikuti arah garis diagonal, maka data menujukkan distribusi normal, maka model regresi memenuhi asumsi normalitas. 
2) Jika data penyebar jauh dari garis diagonal atau tidak mengikuti arah garis diagonal atau grafik historgram tidak menujukkan pola distribusi normal, maka model regresi

tidak memenuhi asumsi normalitas.

b. Uji Autokorelasi

Uji Autokorelasi digunakan untuk mengetahui ada atau tidaknya suatu penyimpangan asumsi klasik autokorelasi yaitu korelasi yang terjadi antara residual pada suatu pengamatan dengan pengamatan lain pada model regresi. Prasyarat yang harus terpenuhi adalah tidak adanya autokorelasi dalam model regresi. Metode pengujian yang sering digunakan adalah dengan uji Durbin Watson (DW test) (Basuki dan Prawoto, 2016:60). Pengambilan keputusan ada tidaknya autokorelasi adalah:

1) Bila d terletak antara batas atas (upper bound / dU) dan 4-dU, maka tidak ada autokorelasi.

2) Bila d lebih rendah dari pada batas bawah (lower bound / dL) dan 4-dL, maka ada autokorelasi.

3) Bila nilai d terletak antara dL dan dU atau di antara (4-dU) dan (4-dL), maka hasilnya tidak dapat disimpulkan.

c. Uji Multikolinearitas

Multikolinieritas atau kolinearitas ganda merupakan adanya hubungan linear antara peubah bebas (X) dalam model regresi ganda. Pendeteksian multikolinieritas dapat dilihat melalui nilai Variance Inflation Factors (VIF) atau dengan melihat nilai Tolerance. Jika nilai VIF $<10$ atau nilai tolerance $>$ 0,10, maka tidak terdapat multikolinearitas di antara variabel independent. dan sebaliknya, jika nilai VIF $>10$ atau nilai tolerance $<0,10$, maka terdapat multikolinearitas. (Basuki dan Prawoto, 2016:62).

d. Uji Heteroskedastisitas

Heteroskedastisitas adalah adanya ketidaksamaan varian dari residual untuk semua pengamatan pada model regresi

(Basuki dan Prawoto, 2016:63). Jika variance dari residual satu pengamatan ke pengamatan yang lain tetap, maka disebut homoskedastisitas dan begitupun sebaliknya, jika variance dari residual satu pengamatan ke pengamatan lain berbeda maka disebut heteroskedastisitas.

Deteksi ada atau tidaknya heteroskedastisitas dapat dilakukan dengan melihat ada tidaknya pola tertentu pada grafik scatterplot antara SRESID dan ZPRED dimana sumbu $\mathrm{Y}$ adalah $\mathrm{Y}$ yang telah diprediksi dan sumbu $\mathrm{X}$ adalah residual (Y prediksi - Y sesungguhnya) yang telah di - studentized. Kriteria dasar dari analisis heteroskedastisitas sebagai berikut :

1) Jika ada pola tertentu seperti titik - titik yang ada membentuk pola tertentu yang teratur (bergelombang, melebar kemudian menyempit), maka mengindikasikan telah terjadi heteroskedastisitas.

2) Jika tidak ada pola yang jelas serta titik-titik menyebar diatas dan dibawah angka 0 pada sumbu Y, maka tidak terjadi heteroskedastisitas.

\section{Pengujian Hipotesis}

\section{a. Uji t (Parsial)}

Untuk mengetahui apakah variabel bebas mempunyai pengaruh yang signifikan terhadap variabel terikat (Basuki dan Prawoto, 2016:88). Uji ini dilakukan dengan syarat:

1) Jika $t_{\text {hitung }}>t_{\text {tabel}}$, variabel independen berpengaruh 
signifikan terhadap variabel dependen.

2) Jika $t_{\text {hitung }}<t_{\text {tabel}}$, maka variabel independen tidak berpengaruh terhadap variabel dependen.

Pengujian juga dapat dilakukan dengan membandingkan nilai signifikansi t dengan tingkat $\alpha$ yang digunakan (dalam penelitian ini menggunakan tingkat $(\alpha)$ sebesar $5 \%$ atau 0,05$)$. Syarat - syaratnya adalah sebagai berikut:

1) Jika signifikansi $t>0,05$, maka variabel independen tidak berpengaruh signifikan terhadap variabel dependen.

2) Jika signifikansi t $<0,05$, maka variabel independen berpengaruh signifikan terhadap variabel dependen.

b. Uji F (Simultan)

Pengujian ini bertujuan untuk mengetahui apakah variabel - variabel bebas (independent) secara simultan atau Bersama - sama mempengaruhi variabel terikat (dependent) (Basuki dan Prawoto, 2016:87). Pengujian ini dapat dilakukan dengan syarat:

1) Jika $f_{\text {hitung }}>f_{\text {tabel}}$, maka variabel independen secara simultan berpengaruh signifikan terhadap variabel dependen.

2) Jika $f_{\text {hitung }}<\mathrm{f}_{\text {tabel}}$, maka variabel independen secara simultan tidak berpengaruh terhadap variabel dependen.

Pengujian ini juga dapat dilakukan dengan membandingkan nilai signifikansi $f$ dengan tingkat $(\alpha)$ yang digunakan (dalam penelitian ini menggunakan tingkat $(\alpha)$ sebesar $5 \%$ atau 0,05$)$. Syarat - syaratnya adalah sebagai berikut:

1) Jika signifikansi f $>0,05$, maka variabel independen secara simultan tidak berpengaruh terhadap variabel dependen.

2) Jika signifikansi $\mathrm{f}<0,05$, maka variabel independen secara simultan berpengaruh signifikan terhadap variabel dependen.

\section{Koefisien Determinasi $\left(\mathbf{R}^{2}\right)$}

Koefisien determinasi $\left(\mathrm{R}^{2}\right)$ adalah koefisien yang menjelaskan hubungan antara variabel dependen dengan variabel independen (Basuki dan Prawoto, 2016:17). Untuk mengetahui besarnya variabel bebas dalam mempengaruhi variabel terikat, dapat diketahui melalui nilai koefisien determinasi yang ditunjukkan oleh nilai $R$ Square $\left(\mathrm{R}^{2}\right)$. Jika $\mathrm{R}^{2}$ mendekati angka 1, maka dapat dikatakan semakin kuat kemampuan variabel bebas dalam model regresi tersebut dalam menerangkan variasi variabel terikatnya. Sebaliknya, jika $\mathrm{R}^{2}$ mendekati angka 0 , maka semakin lemah variabel bebas menerangkan variabel terikat.

\section{Hasil dan pembahasan penelitian}

\section{A. Hasil penelitian}

\section{Deskripsi Responden}

Objek penelitian ini adalah seluruh karyawan yang bekerja pada PT. Bank Tabungan Negara (Persero) Tbk. Cabang Makassar. Jumlah responden yang ditetapkan oleh peneliti yaitu 30 orang dari jumlah karyawan. Berdasarkan hasil penyebaran kuisioner yang telah dilakukan, peneliti membagi karateristik menjadi 4 bagian, yaitu:

\section{a. Deskripsi Responden Berdasarkan Usia}

Adapun hasil kuesioner berdasarkan usia karyawan yang dijadikan sebagai responden adalah sebagai berikut:

\section{Tabel 4.1}

\section{Deskripsi Responden Berdasarkan Usia}




\begin{tabular}{|c|c|c|}
\hline Usia & Frekuensi (Orang) & Persentase \\
\hline$\leq 30$ Tahun & 23 & $77 \%$ \\
\hline$>30-40$ Tahun & 6 & $20 \%$ \\
\hline$>40$ Tahun & 1 & $3 \%$ \\
\hline TOTAL & $\mathbf{3 0}$ & $\mathbf{1 0 0 \%}$ \\
\hline
\end{tabular}

Sumber: Data diolah, 2018

Berdasarkan tabel 4.1 diatas, diketahui bahwa jumlah responden berdasarkan usia $\leq 30$ tahun sebanyak 23 orang atau $77 \%$. Responden yang berusia $>30-40$ Tahun sebanyak 6 orang atau 20\%. Sedangkan usia $>40$ tahun yaitu sebanyak 1 orang atau 3\%. Dengan demikian, dapat disimpulkan bahwa jumlah responden yang berusia $\leq 30$ tahun lebih dominan.

b. Deskripsi Responden Berdasarkan Jenis Kelamin

Adapun hasil kuesioner mengenai jenis kelamin karyawan yang di jadikan sebagai responden adalah sebagai berikut:

Tabel 4.2

Deskripsi Responden Berdasarkan Jenis kelamin

\begin{tabular}{|c|c|c|}
\hline Jenis Kelamin & Frekuensi (Orang) & Persentase \\
\hline Laki - laki & 21 & $70 \%$ \\
\hline Perempuan & 9 & $30 \%$ \\
\hline Total & $\mathbf{3 0}$ & $\mathbf{1 0 0 \%}$ \\
\hline
\end{tabular}

Sumber: Data diolah, 2018

Berdasarkan tabel 4.2 diatas, diketahui bahwa jumlah responden berdasarkan jenis kelamin laki - laki yaitu sebanyak 21 orang atau $70 \%$. Sedangkan responden berdasarkan jenis kelamin perempuan sebanyak 9 orang atau 30\% dari jumlah responden. Dengan demikian, dapat disimpulkan bahwa jumlah responden berdasarkan jenis kelamin laki - laki lebih dominan dibandingkan responden yang berjenis kelamin perempuan.

c. Deskripsi Responden Berdasarkan Tingkat Pendidikan

Adapun hasil kuesioner mengenai tingkat pendidikan karyawan yang di jadikan sebagai responden adalah sebagai berikut:

\section{Tabel 4.3}

Deskripsi Responden Berdasarkan Tingkat Pendidikan

\begin{tabular}{|c|c|c|}
\hline Tingkat Pendidikan & Frekuensi (Orang) & Persentase \\
\hline SMA/SMK/MA & 3 & $10 \%$ \\
\hline DIPLOMA & 5 & $17 \%$ \\
\hline SARJANA & 21 & $70 \%$ \\
\hline PASCASARJANA & 1 & $3 \%$ \\
\hline Total & $\mathbf{3 0}$ & $\mathbf{1 0 0 \%}$ \\
\hline
\end{tabular}

Sumber: Data diolah, 2018

Berdasarkan pada tabel 4.3 menunjukkan bahwa dari 30 responden, karyawan yang memiliki tingkat pendidikan SMA/SMK/MA berjumlah 3 orang atau $10 \%$. Pada tingkat pendidikan DIPLOMA sebanyak 5 orang atau $17 \%$. Pada tingkat pendidikan SARJANA sebanyak 21 orang atau 70\%. Sedangkan pada tingkat pendidikan PASCASARJANA sebanyak 1 orang atau 3\%. Dengan demikian, dapat disimpulkan bahwa jumlah responden dengan tingkat pendidikan SARJANA lebih dominan.

d. Deskripsi Responden Berdasarkan Masa Kerja 
Adapun hasil kuesioner mengenai masa kerja karyawan yang di jadikan sebagai responden adalah sebagai berikut:

\section{Tabel 4.4}

Deskripsi Responden Berdasarkan Masa Kerja

\begin{tabular}{|c|c|c|}
\hline Masa Kerja & Frekuensi (Orang) & Persentase \\
\hline $1-5$ Tahun & 16 & $53 \%$ \\
\hline$>5-10$ Tahun & 11 & $37 \%$ \\
\hline$>10$ Tahun & 3 & $10 \%$ \\
\hline Jumlah & $\mathbf{3 0}$ & $\mathbf{1 0 0 \%}$ \\
\hline
\end{tabular}

Sumber: Data diolah, 2018

Berdasarkan pada tabel 4.4 menunjukkan bahwa dari 30 responden, karyawan yang telah bekerja selama $1-5$ tahun berjumlah 16 orang atau 53\%. Sedangkan karyawan yang telah bekerja selama $>5-10$ tahun berjumlah 11 orang atau 37\% dan karyawan yang telah bekerja selama $>10$ tahun berjumlah 3 orang atau $10 \%$. Dengan demikian, dapat disimpulkan bahwa responden yang telah bekerja selama $>5-10$ tahun lebih dominan.

\section{Uji Instrumen}

\section{a. Uji Validitas}

Hasil perhitungan uji validitas untuk semua variabel dapat dilihat secara lengkap pada tabel dibawah ini: 
Tabel 4.5

Hasil Uji Validitas

\begin{tabular}{|c|c|c|c|c|}
\hline Variabel & Indikator & $\begin{array}{c}\text { Nilai } \\
\text { Korelasi }\end{array}$ & Standar & Ket. \\
\hline \multirow{4}{*}{$\begin{array}{l}\text { Insentif Material } \\
\text { (X1) }\end{array}$} & $\mathrm{X} 1.1$ & 0,871 & 0,30 & Valid \\
\hline & X1.2 & 0,797 & 0,30 & Valid \\
\hline & $\mathrm{X} 1.3$ & 0,813 & 0,30 & Valid \\
\hline & $\mathrm{X} 1.4$ & 0,824 & 0,30 & Valid \\
\hline \multirow{4}{*}{$\begin{array}{c}\text { Insentif Non } \\
\text { Material (X2) }\end{array}$} & $\mathrm{X} 2.1$ & 0,887 & 0,30 & Valid \\
\hline & $\mathrm{X} 2.2$ & 0,855 & 0,30 & Valid \\
\hline & $\mathrm{X} 2.3$ & 0,814 & 0,30 & Valid \\
\hline & $\mathrm{X} 2.4$ & 0,746 & 0,30 & Valid \\
\hline \multirow{4}{*}{$\begin{array}{c}\text { Kepuasan Kerja } \\
(\mathrm{Y})\end{array}$} & Y1.1 & 0,812 & 0,30 & Valid \\
\hline & Y1.2 & 0,777 & 0,30 & Valid \\
\hline & Y1.3 & 0,845 & 0,30 & Valid \\
\hline & Y1.4 & 0,797 & 0,30 & Valid \\
\hline
\end{tabular}

Sumber: Hasil pengolahan data, 2018.

Berdasarkan tabel 4.5 dapat dilihat bahwa instrumen kuesioner Insentif Material (X1), Insentif Non Material (X2), Kepuasan Kerja (Y) dinyatakan valid karena memiliki nilai korelasi $>0,30$ dan nilai signifikan $<0,05$, artinya semua variabel yang dijadikan sebagai indikator sudah tepat untuk dijadikan kuesioner.

b. Uji Reliabilitas

Hasil perhitungan uji reliabilitas untuk semua variabel dapat dilihat secara lengkap pada tabel dibawah ini :

Tabel 4.6

Hasil Uji Reliabilitas

\begin{tabular}{|c|c|c|c|c|}
\hline No. & Variabel & $\begin{array}{c}\text { Cronbach's } \\
\text { Alpha }\end{array}$ & $\begin{array}{c}\text { Alpha } \\
\text { Table }\end{array}$ & Keterangan \\
\hline 1. & $\begin{array}{c}\text { Insentif } \\
\text { Material }\end{array}$ & 0,842 & 0,60 & Reliabel \\
\hline 2. & $\begin{array}{c}\text { Insentif Non } \\
\text { Material }\end{array}$ & 0,842 & 0,60 & Reliabel \\
\hline 3. & $\begin{array}{c}\text { Kepuasan } \\
\text { Kerja }\end{array}$ & 0,820 & 0,60 & Reliabel \\
\hline
\end{tabular}

Sumber: Hasil pengolahan data, 2018. 
Berdasarkan tabel 4.6 diatas, setiap variabel memiliki hasil nilai koefisien Cronbach's Alpha $>0,6$. Artinya instrumen yang digunakan sebagai alat ukur variabel sudah reliabel.

\section{Analisis Regresi Linear Berganda}

Analisis regresi dalam penelitian ini digunakan untuk mengetahui pengaruh insentif material dan non material terhadap kepuasan kerja karyawan pada PT. Bank Tabungan Negara (Persero) Tbk. Cabang Makassar. Tingkat kepercayaan yang digunakan dalam penelitian ini adalah $95 \%(\alpha=0,05)$. Hasil analisis regresi linear berganda dapat dilihat pada tabel dibawah ini:

Tabel 4.7

Hasil Analisis Regresi Linear Berganda Coefficients $^{\text {a }}$

\begin{tabular}{|c|c|c|c|c|c|}
\hline \multirow{2}{*}{ Model } & \multicolumn{2}{|c|}{$\begin{array}{l}\text { Unstandardized } \\
\text { Coefficients }\end{array}$} & \multirow{2}{*}{$\begin{array}{c}\begin{array}{c}\text { Standardiz } \\
\text { ed } \\
\text { Coefficien } \\
\text { ts }\end{array} \\
\text { Beta }\end{array}$} & \multirow{2}{*}{$\mathrm{T}$} & \multirow{2}{*}{ Sig. } \\
\hline & B & $\begin{array}{l}\text { Std. } \\
\text { Error }\end{array}$ & & & \\
\hline 1 (Constant) & 2.421 & 1.925 & & 1.258 & .219 \\
\hline Insentif Material & .518 & .211 & .538 & 2.459 & .021 \\
\hline $\begin{array}{l}\text { Insentif Non } \\
\text { Material }\end{array}$ & .340 & .225 & .331 & 1.511 & 142 \\
\hline
\end{tabular}

Sumber: Hasil pengolahan data, 2018.

Berdasarkan hasil analisis regresi pada tabel 4.9, dapat dibuat

model persamaan regresi pengaruh insentif material dan non material terhadap kepuasan kerja sebagai berikut:

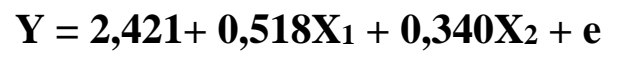

Berdasarkan persamaan regresi diatas, sehingga dapat diuraikan sebagai berikut:

a. Koefisien konstanta bernilai 2,421 yang berarti positif artinya bahwa jika variabel insentif material dan insentif non material nilainya 0 atau tetap (konstan), maka akan mempengaruhi kepuasan kerja karyawan pada PT. Bank Tabungan Negara (Persero) Tbk. Cabang Makassar sebesar 2,421.

b. Koefisien regresi X1 variabel insentif material dimana memperoleh nilai positif 0,518, menyatakan bahwa insentif material mempunyai pengaruh positif terhadap kepuasan kerja karyawan karena memiliki nilai positif. Hal ini berarti setiap kenaikan insentif material, akan meningkatkan nilai kepuasan kerja karyawan pada PT. Bank Tabungan Negara (Persero) Tbk. Cabang Makassar sebesar 0,518 .

Koefisien regresi X2 variabel insentif non material dimana memperoleh nilai positif 0,340 , menyatakan bahwa insentif material mempunyai pengaruh positif terhadap kepuasan kerja karyawan karena memiliki nilai positif. Hal ini berarti setiap kenaikan satuan insentif non material, akan meningkatkan nilai kepuasan kerja karyawan pada PT. Bank Tabungan Negara (Persero) Tbk. Cabang Makassar sebesar 0,340. 


\section{Uji Asumsi Klasik}

a. Uji Normalitas

Adapun hasil uji normalitas dapat dilihat pada gambar dibawah ini:

\section{Gambar 4.1}

\section{Hasil Uji Normalitas}

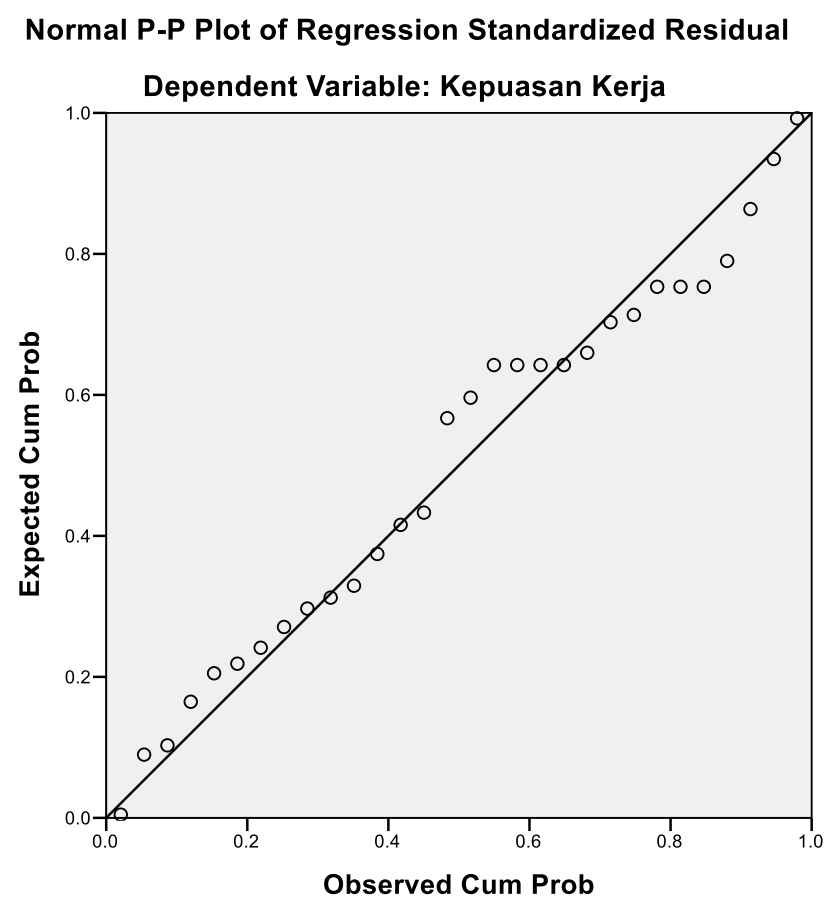

Model regresi yang baik adalah apabila memiliki nilai residual yang berdistribusi normal. Dari gambar 4.1 diatas, dapat dilihat bahwa titik - titik tersebar disepanjang garis diagonal dan mengikuti arah garis diagonal. Artinya nilai residual yang ditunjukkan berdistribusi normal. Dengan begitu, uji normalitas telah terpenuhi sehingga dapat melanjutkan pengujian analisis data selanjutnya.

b. Uji Autokorelasi

Adapun hasil uji autokorelasi dapat dilihat pada tabel dibawah ini:

Tabel 4.8

Hasil Uji Autokorelasi

Model Summary ${ }^{b}$

\begin{tabular}{|c|c|c|c|c|c|c|c|}
\hline \multirow[b]{2}{*}{ Model } & \multirow[b]{2}{*}{$\mathrm{R}$} & \multicolumn{5}{|c|}{ Change Statistics } & \multirow[b]{2}{*}{$\begin{array}{l}\text { Durbin- } \\
\text { Watson }\end{array}$} \\
\hline & & $\begin{array}{l}\text { R Square } \\
\text { Change }\end{array}$ & $\begin{array}{c}\mathrm{F} \\
\text { Chang } \\
\mathrm{e}\end{array}$ & $\begin{array}{c}\mathrm{df} \\
1\end{array}$ & $\begin{array}{l}\text { df } \\
2\end{array}$ & $\begin{array}{c}\text { Sig. F } \\
\text { Chang } \\
\mathrm{e} \\
\end{array}$ & \\
\hline 1 & $.884^{\mathrm{a}}$ & .713 & 33.485 & 2 & 27 & .000 & 2.429 \\
\hline
\end{tabular}

Sumber: Hasil pengolahan data, 2018.

Berdasarkan tabel 4.7 di atas, menyatakan bahwa DW yang dihasilkan dari model regresi adalah 2,429. Diketahui nilai dU sebesar 1,567 dan 4 - dU sebesar 
2,433. Dari hasil tabel 4.7 diatas, diperoleh nilai Durbin - Watson sebesar 2,429. Maka d terletak diantara batas atas (dU) dan 4 - dU. Sehingga dapat disimpulkan bahwa tidak terjadi autokorelasi dalam model regresi ini.

\section{c. Uji Multikolinearitas}

Adapun hasil uji multikolinearitas dapat dilihat pada tabel dibawah ini:

Tabel 4.9

Hasil Perhitungan Uji Multikolinearitas

\begin{tabular}{|l|c|c|c|}
\hline \multirow{2}{*}{ Variabel } & \multicolumn{2}{|c|}{ Collinearity Statistic } & \multirow{2}{*}{ Interpretasi } \\
\cline { 2 - 3 } & Tolerance & VIF & \\
\hline Insentif Material & 0,222 & 4,501 & $\begin{array}{c}\text { Tidak terdapat } \\
\text { multikolinearitas }\end{array}$ \\
\hline $\begin{array}{l}\text { Insentif Non } \\
\text { Material }\end{array}$ & 0,222 & 4,501 & $\begin{array}{c}\text { Tidak terdapat } \\
\text { multikolinearitas }\end{array}$ \\
\hline
\end{tabular}

Sumber : Hasil pengolahan data, 2018.

Model regresi yang baik adalah apabila tidak terdapat multikolinearitas. Berdasarkan pada nilai toleransi dan VIF pada tabel 4.8 diatas, terlihat bahwa tidak ada nilai toleransi dibawah 0,1 (nilai toleransi sebesar 0,222). Begitu juga dengan nilai VIF tidak ada yang diatas 10 (nilai VIF sebesar 4,501). Jadi, dapat disimpulkan bahwa tidak terdapat multikolinearitas. Artinya tidak terdapat hubungan yang erat atau korelasi sempurna di antara variabel - variabel bebas dalam model regresi ini. Dengan begitu, syarat uji multikolinearitas telah terpenuhi sehingga dapat melanjutkan pengujian analisis data selanjutnya.

d. Uji Heteroskedastisitas

Adapun hasil uji heteroskedastisitas dapat dilihat pada gambar dibawah ini:

\section{Gambar 4.2}

'Uji Heteroskedastisitas

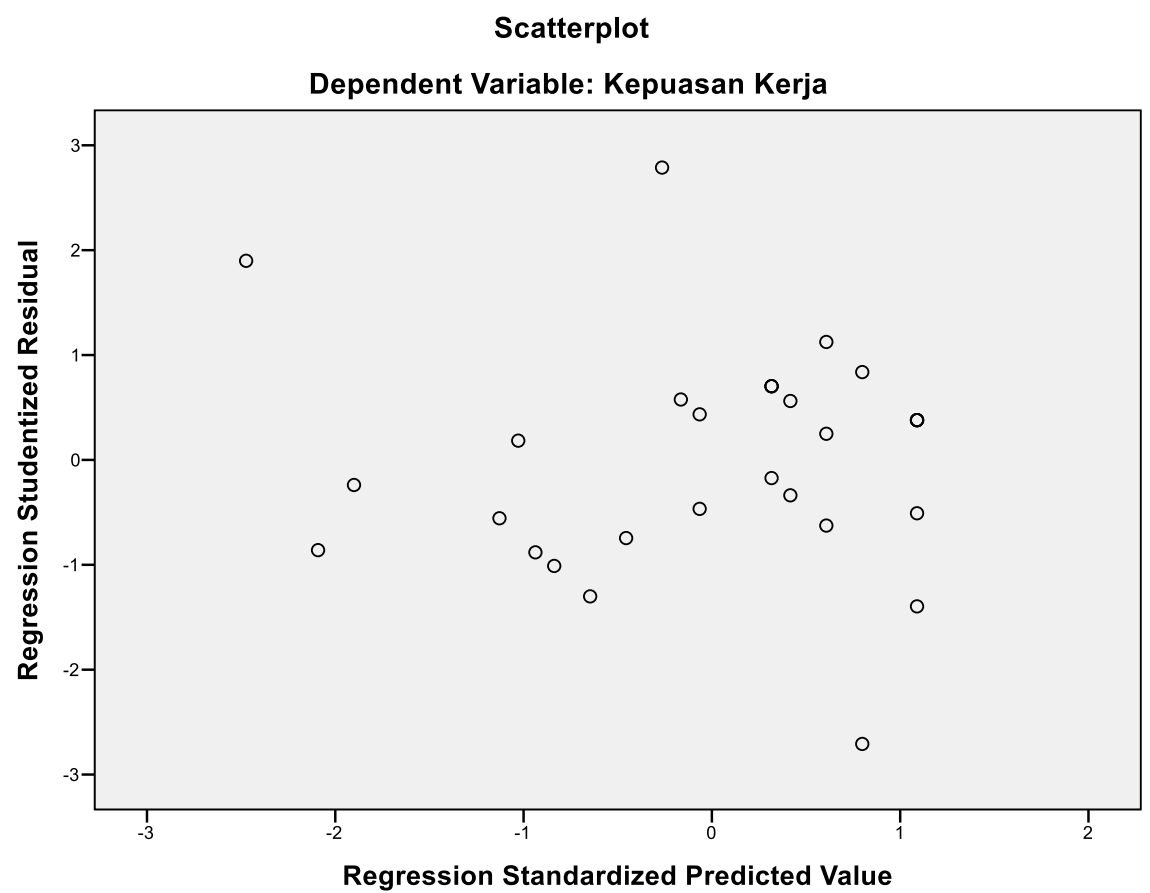

Model regresi yang baik adalah apabila tidak terjadi heteroskedastisitas. Berdasarkan hasil pengolahan data pada gambar 4.2 diatas, menunjukkan bahwa titik - titik menyebar diatas dan dibawah angka 0 dan tidak 
membentuk pola pada sumbu Y. Sehingga dapat disimpulkan bahwa tidak terjadi heteroskedastisitas pada model regresi ini. Artinya, ada kesamaan varian dari residual untuk semua pengamatan pada model regresi. Dengan begitu, syarat uji heteroskedastisitas telah terpenuhi.

\section{Pengujian Hipotesis}

a. Uji t (Parsial)

Adapun hasil uji t (parsial) dapat dilihat pada tabel dibawah ini:

Tabel 4.10

Hasil Uji t (Parsial)

\begin{tabular}{|c|r|r|r|r|r|}
\hline \multirow{2}{*}{ Model } & \multicolumn{2}{|c|}{$\begin{array}{c}\text { Unstandardized } \\
\text { Coefficients }\end{array}$} & $\begin{array}{c}\text { Standardize } \\
\mathrm{d} \\
\text { Coefficient } \\
\mathrm{s}\end{array}$ & \multirow{2}{*}{$\mathrm{T}$} & Sig. \\
\cline { 2 - 4 } & $\mathrm{B}$ & $\begin{array}{c}\text { Std. } \\
\text { Error }\end{array}$ & Beta & & \\
\hline $1 \quad$ (Constant) & 2.421 & 1.925 & & 1.258 & .21 \\
9 \\
Insentif Material
\end{tabular}

Sumber: Hasil pengolahan data, 2018.

Diketahui nilai $t_{\text {tabel }}$ dalam penelitian ini adalah sebesar 2,055. Nilai tersebut diperoleh dengan cara mencari nilai $\mathrm{df}=\mathrm{t}(\alpha: 2: \mathrm{n}-\mathrm{k}-1)$ dan taraf signifikansi $(\alpha)$ yaitu 0,05 . Sehingga diperoleh nilai $\mathrm{df}=\mathrm{t}(0,05 / 2: \mathrm{n}-\mathrm{k}-1)=\mathrm{t}(0,025: 30-3-1)=\mathrm{t}(0,025: 26)$. Berdasarkan tabel 4.10 diatas, di peroleh hasil sebagai berikut :

1) Hipotesis pertama pada penelitian ini adalah insentif material berpengaruh secara positif dan signifikan terhadap kepuasan kerja karyawan pada PT. Bank Tabungan Negara (Persero) Tbk. Cabang Makassar.

Berdasarkan hasil uji t pada tabel 4.10 diatas, diketahui bahwa nilai thitung $>$

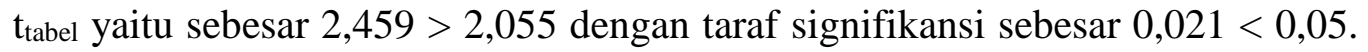
Hal ini menunjukkan bahwa insentif material berpengaruh signifikan terhadap kepuasan kerja kayawan. Artinya insentif material mempengaruhi kepuasan kerja karyawan pada PT. Bank Tabungan Negara (Persero) Tbk. Cabang Makassar. Dengan demikian hipotesis pertama (H1) diterima.

2) Hipotesis kedua pada penelitian ini adalah insentif non material berpengaruh secara positif dan tidak signifikan terhadap kepuasan kerja karyawan pada PT. Bank Tabungan Negara (Persero) Tbk. Cabang Makassar.

Berdasarkan hasil uji t pada tabel 4.10 diatas, diketahui bahwa nilai $t_{\text {hitung }}<$ $\mathrm{t}_{\text {tabel }}$ yaitu sebesar 1,511<2,055 dengan taraf signifikansi sebesar 0,142>0,05. Hal ini menunjukkan bahwa insentif non material berpengaruh tidak signifikan terhadap kepuasan kerja karyawan. Artinya insentif non material mempengaruhi kepuasan kerja tetapi tidak signifikan pada karyawan PT. Bank Tabungan Negara (Persero) Tbk. Cabang Makassar. Dengan demikian hipotesis kedua (H2) ditolak.

a. Uji F (Simultan)

Adapun hasil uji F (simultan) dapat dilihat pada tabel dibawah ini:

\section{Tabel 4.11}




\begin{tabular}{|c|c|c|c|c|c|c|}
\hline & & $\begin{array}{r}\text { Hasil L } \\
\text { ANO }\end{array}$ & $\begin{array}{l}\mathbf{F}(\mathbf{s} \\
\mathbf{A}^{\mathrm{a}}\end{array}$ & multan) & & \\
\hline & & $\begin{array}{c}\text { Sum of } \\
\text { Squares }\end{array}$ & Df & $\begin{array}{l}\text { Mean } \\
\text { Square }\end{array}$ & $\mathrm{F}$ & Sig. \\
\hline 1 & Regression & 91.912 & 2 & 45.956 & 33.458 & $.000^{\mathrm{b}}$ \\
\hline & Residual & 37.055 & 27 & 1.327 & & \\
\hline & Total & 128.967 & 29 & & & \\
\hline
\end{tabular}

Sumber: Hasil pengolahan data, 2018.

Diketahui nilai $F_{\text {tabel }}$ dalam penelitian ini adalah 2,98. Nilai tersebut diperoleh dengan cara ( $\mathrm{V} 1=\mathrm{k}: \mathrm{V} 2=\mathrm{n}-\mathrm{k}-1$ atau 3:26), sehingga diperoleh nilai $F=(2,98)$. Dari hasil Uji $F$ diatas, menunjukkan bahwa nilai $F_{\text {hitung }}>F_{\text {tabel }}$ yaitu 33,458 $>2,98$ dengan signifikansi $0,000<0,05$, maka dapat disimpulkan bahwa variabel insentif material dan insentif non material secara simultan berpengaruh signifikan terhadap kepuasan kerja karyawan. Artinya semua variabel tersebut mampu mempengaruhi kepuasan kerja karyawan pada PT. Bank Tabungan Negara (Persero) Tbk. Cabang Makassar. Dengan demikian hipotesis ketiga (H3) diterima.

\section{Koefisien Determinasi $\left(\mathbf{R}^{2}\right)$}

Adapun hasil uji koefisien determinasi dapat dilihat pada tabel dibawah ini:

Tabel 4.12

Hasil Uji Koefisien Determinasi $\left(\mathbf{R}^{2}\right)$ Model Summary ${ }^{b}$

\begin{tabular}{|c|c|c|c|c|}
\hline Model & $\mathrm{R}$ & R Square & $\begin{array}{c}\text { Adjusted R } \\
\text { Square }\end{array}$ & $\begin{array}{c}\text { Std. Error of the } \\
\text { Estimate }\end{array}$ \\
\hline 1 & $.844^{\mathrm{a}}$ & .713 & .691 & 1.171 \\
\hline
\end{tabular}

Sumber : Hasil pengolahan data, 2018.

Berdasarkan tabel 4.16 diatas, dapat diketahui bahwa nilai $R$ Square $\left(\mathrm{R}^{2}\right)$ sebesar 0,713. Artinya kepuasan kerja karyawan pada PT. Bank Tabungan Negara (Persero) Tbk. Cabang Makassar yang dipengaruhi oleh variabel insentif material dan insentif non material adalah sebesar $71,3 \%$. Sedangkan sisanya sebesar $28,7 \%$ dipengaruhi oleh variabel lain yang tidak dimasukkan dalam penelitian ini.

\section{Pembahasan}

Hasil analisis pengaruh variabel insentif material dan non material terhadap kepuasan kerja karyawan pada PT. Bank Tabungan Negara (Persero) Tbk. Cabang Makassar sebagaimana dapat dilihat pada lampiran, yang dimana menghasilkan nilai koefisien determinasi ( $R$ Squared atau $\mathrm{R}^{2}$ ) $=0,713$. Ini berarti bahwa besarnya konstribusi yang diberikan oleh variabel independen terhadap variabel dependen yaitu sebesar 71,3\%, selebihnya $28,7 \%$ dijelaskan oleh variabel lain yang tidak diteliti. Koefisien determinasi tersebut sangat tinggi dikarenakan menggunakan dua variabel bebas, yaitu insentif material dan non material. Hal ini dapat diartikan bahwa variabel bebas yang diteliti sangat baik digunakan untuk mengukur kepuasan kerja karyawan. Dengan kata lain, insentif material dan non material dianggap penting untuk dipertimbangkan dalam mengukur kepuasan kerja karyawan. 
Untuk mengetahui nilai signifikansi pengaruh insentif material dan non material terhadap kepuasan kerja karyawan pada PT. Bank Tabungan Negara (Persero) Tbk. Cabang Makassar secara parsial atau sendiri - sendiri dapat dilakukan dengan menggunakan uji t. Selain itu, untuk mengetahui nilai signifikansi insentif material dan non material terhadap kepuasan kerja karyawan secara simultan atau bersama - sama, dapat dilakukan dengan menggunakan uji F. Dengan begitu, akan diketahui apakah terdapat pengaruh atau tidak antara variabel bebas terhadap variabel terikat.

\section{Pengaruh Insentif Material Terhadap Kepuasan Kerja Karyawan Pada PT. Bank Tabungan Negara (Persero) Tbk. Cabang Makassar.}

Berdasarkan hasil uji koefisien regresi yang telah dilakukan menunjukkan bahwa variabel insentif material mempunyai pengaruh positif terhadap kepuasan kerja. Besarnya insentif yang diberikan kepada karyawan, maka kepuasan karyawan tersebut juga meningkat. Hal tersebut ditunjukkan variabel insentif material yang diberikan kepada karyawan berpengaruh pada kepuasan mereka, dan hasil uji diketahui sebesar 0,518 atau 51,8\% dengan tingkat signifikansi 0,021 yang sudah cukup membuktikan jika insentif material berpengaruh positif dan signifikan terhadap kepuasan kerja. Selain itu, dari analisis pada variabel insentif material sudah sesuai dengan kinerja dan harapan karyawan memiliki kategori baik yang berarti insentif material yang diberikan PT. Bank Tabungan Negara (Persero) Tbk. Cabang Makassar sudah baik. Setiap karyawan pasti menginginkan imbalan selain upah / gaji apabila mereka dapat bekerja dengan baik dan melebihi standar perusahaan yang ditetapkan. Insentif material dalam hasil penelitian ini merupakan variabel yang paling dominan pengaruhnya terhadap kepuasan kerja karyawan jika dibandingkan dengan variabel insentif non material, dimana insentif material sebesar 0,518 sedangkan insentif non material sebesar 0,340 . Hal tersebut bisa terjadi karena nilai insentif material berupa bonus, komisi, dan kompensasi pada PT. Bank Tabungan Negara (Persero) Tbk. Cabang Makassar lebih besar. Dengan demikian, PT. Bank Tabungan Negara (Persero) Tbk. Cabang Makassar telah memberikan insentif material yang sesuai dengan kinerja dan harapan karyawan, maka karyawan mendapat kepuasan kerja yang tinggi.

Temuan ini tidak bertentangan dengan hasil penelitian yang dilakukan oleh Zaputri (2013) yang dimana menunjukkan bahwa insentif material berpengaruh secara positif dan signifikan terhadap kepuasan kerja karyawan.

2. Pengaruh Insentif Non Material Terhadap Kepuasan Kerja Karyawan Pada PT. Bank Tabungan Negara (Persero) Tbk. Cabang Makassar.

Berdasarkan hasil uji koefisien regresi yang telah dilakukan menunjukkan bahwa variabel insentif non material mempunyai pengaruh positif terhadap kepuasan kerja. Besarnya insentif non material yang diberikan kepada karyawan, maka kepuasan karyawan tersebut cenderung semakin meningkat. Hal tersebut ditunjukkan variabel insentif material yang diberikan kepada karyawan berpengaruh pada kepuasan mereka, dan hasil uji diketahui sebesar 0,340 atau 34\% dengan tingkat signifikansi 0,142 yang sudah cukup membuktikan jika insentif non material berpengaruh positif tapi tidak signifikan terhadap kepuasan kerja. Insentif non material berupa penghargaan dan pemberian pujian pada karyawan yang bekerja dengan baik dan melebihi standar perusahaan yang ditetapkan dapat memberikan kepuasan kerja.

Setiap karyawan pasti menginginkan adanya pemberian penghargaan dan pujian apabila mereka dapat bekerja dengan baik dan melebihi standar perusahaan yang ditetapkan. Insentif non material dalam hasil penelitian ini merupakan variabel yang 
paling rendah pengaruhnya terhadap kepuasan kerja karyawan jika dibandingkan dengan variabel insentif material, dimana insentif non material sebesar 0,340 sedangkan insentif material sebesar 0,518 . Hal tersebut bisa terjadi karena nilai insentif non material berupa pemberian penghargaan dan pujian pada PT. Bank Tabungan Negara (Persero) Tbk. Cabang Makassar lebih kecil. Dengan demikian, meskipun PT. Bank Tabungan Negara (Persero) Tbk. Cabang Makassar telah memberikan insentif non material berupa penghargaan dan pujian karena telah bekerja dengan baik, namun belum belum tentu dapat meningkatkan kepuasan kerja karyawannya.

Temuan ini bertentangan dengan hasil penelitian yang dilakukan oleh Natasari (2012) yang dimana menunjukkan bahwa insentif non material berpengaruh secara positif dan signifikan terhadap kepuasan kerja karyawan.

3. Pengaruh Insentif Material dan Non Material Secara Bersama - Sama Terhadap Kepuasan Kerja Karyawan Pada PT. Bank Tabungan Negara (Persero) Tbk. Cabang Makassar.

Berdasarkan hasil uji F pada tabel 4.11, diperoleh hasil F sebesar 33,458 dengan nilai signifikasi $0,000<0,05$. Hal ini menunjukkan bahwa insentif material dan non material secara simultan berpengaruh signifikan terhadap kepuasan kerja karyawan. Hal ini menunjukkan model regresi linear berganda dalam penelitian ini dapat digunakan untuk mengukur kepuasan kerja yang dipengaruhi oleh insentif material dan non material.

\section{Kesimpulan}

Berdasarkan hasil penelitian dan pembahasan, maka dapat diambil kesimpulan sebagai berikut:

1. Variabel insentif material berpengaruh secara positif dan signifikan. Insentif material dapat mempengaruhi kepuasan kerja karyawan pada PT. Bank Tabungan Negara (Persero) Tbk. Cabang Makassar. Hal ini berarti bahwa semakin sesuai jumlah insentif material diterima oleh karyawan maka akan semakin meningkatkan kepuasan kerja karyawan.

2. Variabel insentif non material berpengaruh secara positif tapi tidak signifikan. Insentif non material dapat mempengaruhi kepuasan kerja karyawan pada PT. Bank Tabungan Negara (Persero) Tbk. Cabang Makassar. Hal ini berarti bahwa insentif non material yang diberikan kepada karyawan telah adil dan sesuai dengan pekerjaannya, namun tidak terlalu berarti pengaruhnya terhadap kepuasan kerja karyawan.

3. Variabel insentif material dan non material secara simultan berpengaruh signifikan. Hal ini berarti bahwa Insentif material dan non material secara bersama - sama dapat mempengaruhi kepuasan kerja karyawan pada PT. Bank Tabungan Negara (Persero) Tbk. Cabang Makassar.

\section{Daftar Pustaka}

Badriyah, M. 2015. Manajemen Sumber Daya Manusia, Cetakan 1. Bandung : CV Pustaka Setia.

Basuki dan Prawoto. 2016. Analisis Regresi Dalam Penelitian Ekonomi \& Bisnis Dilengkapi Aplikasi SPSS Eviews. Edisi 1, Depok : PT Rajagrafindo Persada.

Ghozali, Imam. 2016. Aplikasi Analisis Multivariete Dengan Program IBM SPSS 23. Semarang : Badan Penerbit Universitas Diponegoro.

Handoko, T. Hani. 2008. Manajemen Personalia Sumber Daya Manusia, Edisi Kedua, Yogyakarta : BPFE. 
Hasibuan, Malayu. 2013. Manajemen Sumber Daya Manusia, Jakarta: PT Bumi Aksara.

Mangkunegara, A.A. Anwar Prabu. 2011. Manajemen Sumber Daya Manusia Perusahaan. Bandung: PT. Remaja Rosdakarya.

Natasari. 2012. "Pengaruh Pemberian Insentif Material Dan Non Material Terhadap Kinerja Karyawan Melalui Kepuasan Kerja (Studi pada PG Kebon Agung Malang)" : Universitas Brawijaya, Malang.

Nawawi. 2011. Manajemen Sumber Daya Manusia: Untuk Bisnis Yang Kompetitif. Gajahmada University Press. Yogyakarta.

Panggabean, Mutiara S. 2002. Manajemen Sumber Daya Manusia. Bogor: Ghalia Indonesia.

Robbins, Stephen P. 2006. Perilaku Organisasi. Alih Bahasa : Benyamin Molan. Edisi Kesepuluh. Penerbit PT. Indeks, Kelompok Gramedia, Jakarta.

Sarwoto. 2010. Dasar Dasar Organisasi dan Manajemen. Jakarta : Ghalia Indonesia.

Siagian, Sondang. 2007. Manajemen Sumber Daya Manusia. Jakarta : PT. Bumi Aksara.

Sirait. 2006. Memahami Aspek - Aspek Pengelolaan Sumber Daya Manusia dalam Organisasi. Gramedia Widiasarana Indonesia, Jakarta.

Sugiyono, 2017. Metode Penelitian Kuantitatif, Kualitatif, dan Kombinasi (Mixxed Methods). Alfabeta CV.

Sutrisno, Edy. 2011, Manajemen Sumber Daya Manusia, Jakarta: Kencana.

Suwatno. 2011. Manajemen SDM dalam organisasi Publik dan Bisnis. Bandung : Alfabeta.

Yulharsari. 2012. "Pengaruh Kepemimpinan, Kompensasi Dan Budaya Organisasi Terhadap Kepuasan Kerja Karyawan”, Jurnal, Universitas Gunadarma, Jakarta.

Zaputri, A. R., Rahardjo, K. dan Utami, H. N. (2013). "Pengaruh Insentif Material Dan Insentif Non Material Terhadap Kepuasan Kerja Dan Kinerja Karyawan: Studi Pada Karyawan Produksi Cetak PT. Temprina Media Grafika Surabaya".

Republik Indonesia 1969, Undang - Undang NO/14/1969, Tentang Ketentuan - Ketentuan Pokok Mengenai Tenaga Kerja

Republik Indonesia 2003, Undang - Undang NO/13/2003, Tentang Ketenagakerjaan https://www.btn.co.id/id/Tentang-Kami 